\title{
A mini-review on paroxysmal nocturnal hemoglobinuria and a case of Eculizumab treatment of PNH in elderly MDS patient
}

\section{Galina A. Dudina}

Moscow Clinical Research Center, Moscow Health Department, Moscow, Russian Federation

Dudina Galina A., PhD (Medicine), Senior Research Associate, Department of Oncohematology and Secondary Immunodeficiencies, The Moscow Clinical Research Center of Moscow Health Department, Entusiastov Ave 86, 111123, Moscow, Russian Federation

\section{Summary}

Paroxysmal nocturnal hemoglobinuria $(\mathrm{PNH})$ is a systemic, acquired clonal hematological disorder which results from loss of complement-inhibiting proteins (CD55 and CD 59) from the blood cell surface. Therefore, such patients develop chronic complement-mediated intravascular hemolysis, with thromboses manifesting as most severe clinical complications. Recommendations of International PNH groups discern certain risk groups based on detection of a pathological cell clone, including
Phone: +7 (916) 6508577

E-mail: dudina_gal@mail.ru patients with myelodysplastic syndrome (MDS). Here we describe detection of a clinically sound $\mathrm{PNH}$ clone in an elderly patient with MDS, as well as positive results of patho-genetic treatment with Eculizumab.

\section{Keywords}

Paroxismal nocturnal hemoglobinuria, myelodysplastic syndrome, diagnostics, Eculizumab.

\section{Introduction}

Paroxysmal nocturnal hemoglobinuria $(\mathrm{PNH})$ is a rare acquired chronic disease of hematopoietic stem cells (HSC) characterized by chronic intravascular hemolysis, bone marrow failure and increased risk of thrombotic complications. PNH occurs due to a non-malignant clonal expansion of mutated HSCs with an acquired somatic X-linked mutation in the phosphatidylinositol glycan A gene (PIG-A) [2, 22]. This mutation causes altered glycosylphosphatidylinositol (GPI anchor) binding to some surface proteins, e.g., CD55 and CD 59 complement-inhibitors. Loss of these regulatory proteins predisposes for non-controlled complement activation resulting to intravascular destruction of red blood cells
(RBC), thus manifesting as chronic hemolysis and progressing anemia $[12,22]$. However, sole PIG-A mutation is not sufficient for expansion of a PNH clone and clinical symptoms. Precise mechanisms of the clonal expansion are not yet known, probably, being coupled to bone marrow failure [12, 21]. Such physiological mechanism is confirmed by higher incidence of $\mathrm{PNH}$ clone in patients with aplastic anemia (AA) and myelodysplastic syndrome (MDS) $[11,18,27,26$, 29, 30].

Table 1 shows results of international clinical studies for $\mathrm{PNH}$ clone assessment in the patients with different MDS subtypes. 
Table 1. Identification and distribution of PNH clones in the patients with different subtypes of myelodysplastic syndrome (MDS)

\begin{tabular}{|c|c|c|c|c|c|c|}
\hline $\begin{array}{l}\text { No of } \\
\text { cases } \\
\text { (reference } \\
\text { No) }\end{array}$ & Country & $\begin{array}{l}\text { Diagnostic } \\
\text { technique }\end{array}$ & Cells studied & $\begin{array}{l}\text { Sensitivity } \\
\text { threshold }\end{array}$ & $\begin{array}{l}\text { Percentage of } \\
\text { patients with } \\
\text { detectable PNH } \\
\text { clone (number } \\
\text { of cases)0 }\end{array}$ & $\begin{array}{l}\text { Distribution of PNH } \\
\text { clones in MDS subtypes }\end{array}$ \\
\hline $585^{18}$ & USA & $\begin{array}{l}\text { Flow } \\
\text { cytometry }\end{array}$ & $\begin{array}{l}\text { CD59-RBCs } \\
\text { FLAER/CD24-granu- } \\
\text { locytes } \\
\text { FLAER/CD14-mono- } \\
\text { cytes }\end{array}$ & $0.01 \%$ & $5.5 \%(32 / 585)$ & $\begin{array}{l}\text { LGMDSL } \\
\text { HGMDSL } \\
\text { MDS w/5q deletion } \\
\text { MAC, non-specified } \\
\text { Myelofibrosis } \\
\text { w/myeloid metaplasia } \\
\text { (subtype distribution not } \\
\text { shown) }\end{array}$ \\
\hline $316^{27}$ & Japan & $\begin{array}{l}\text { Flow } \\
\text { cytometry }\end{array}$ & $\begin{array}{l}\text { CD59-/CD55-/CD11b+ } \\
\text { granulocytes } \\
\text { and CD59-/CD55-/ } \\
\text { GP-A+ RBCs }\end{array}$ & $\begin{array}{l}\geq 0.003 \% \text { gran- } \\
\text { ulocytes and } \\
\geq 0.005 \% \mathrm{RBCs}\end{array}$ & $20 \%(64 / 316)$ & RA: 64/316 (20\%) \\
\hline $136^{29}$ & USA & $\begin{array}{l}\text { Flow } \\
\text { cytometry }\end{array}$ & $\begin{array}{l}\text { CD55-/CD59- and/or } \\
\text { CD16-/CD66b- } \\
\text { granulocytes }\end{array}$ & $0.01 \%$ & $6.6 \%(9 / 136)$ & $\begin{array}{l}\text { RA: 6/17 (35\%) } \\
\text { 5q:1/5 (20\%) } \\
\text { RCMD: } 2 / 37 \text { (5\%) }\end{array}$ \\
\hline $164^{28}$ & Japan & $\begin{array}{l}\text { Flow } \\
\text { cytometry }\end{array}$ & $\begin{array}{l}\text { CD59-/CD55-granu- } \\
\text { locytes and RBCs }\end{array}$ & $\begin{array}{l}0.003 \% \text { CD55- } \\
\text { CD59- granulo- } \\
\text { cytes and RBCs }\end{array}$ & $12.8 \%(21-164)$ & $\begin{array}{l}\text { RA: } 21 / 119 \text { (17.6\%) } \\
\text { RARS: } 0 / 4 \\
\text { RAEB: } 0 / 33 \\
\text { RAEBt: } 0 / 8\end{array}$ \\
\hline $25^{30}$ & Turkey & $\begin{array}{l}\text { Flow } \\
\text { cytometry }\end{array}$ & $\begin{array}{l}\text { CD55-/CD59 - leu- } \\
\text { kocytes }\end{array}$ & $\begin{array}{l}\geq M \pm 1.96 \times S D \text { for } \\
\text { controls }\end{array}$ & $24 \%(6 / 25)$ & $\begin{array}{l}\text { RA: } 4 / 17 \text { (23.5\%) } \\
\text { RARS: } 1 / 2 \\
\text { RAEB: } 1 / 4 \\
\text { CMML: } 0 / 2\end{array}$ \\
\hline $38^{21}$ & Japan & $\begin{array}{l}\text { Flow } \\
\text { cytometry }\end{array}$ & CD55-/CD59-RBCs & No data & $15.7 \%(6 / 38)$ & $\begin{array}{l}\text { RA: } 5 / 33 \text { (15.1\%) } \\
\text { RARS: } 1 / 1 \\
\text { RAEB: } 0 / 4\end{array}$ \\
\hline
\end{tabular}

Note: PNH, paroxysmal nocturnal hemoglobinuria; MDS, Myelodysplastic syndrome ; CMML, chronic myelomonocytic leukemia; FLAER, fluorescent aerolysine; HGMDSL, high-risk MDS; hMDS, hypoplastic MDS variant, LGMDSL, low-risk MDS; MDS-U, MDS non-classified; RA, refractory anemia; RAEB(1/2), RA with blast excess (1/2); RAEBt, RA with blast excess and acute leukemia transformation; RAMD, RA with multilineage dysplasia; RARS, RA with ring syderoblasts; RCMD, RA with multilineage dysplasia; RCMDRS, RA with multilineage dysplasia and ring syderoblasts; 5q, 5q syndrome.

As seen from a series of studies (Table 1), incidence of PNH clone in MDS patients varies from $5.5 \%$ to $24 \%$ cases (a mean of $13 \%$ ). PNH manifestations are highly different, and the disease may develop at any age (a median of 30-40 years old) $[8,22]$. Life-threatening complications occur, as a rule, due to uncontrollable complement-mediated hemolysis and consequent blood platelet activation [3, 10, 19]. Most common clinical symptoms include anemia (88\%) [3], thrombosis (35\%) [9], chronic kidney disease (64\%) [10], abdominal pains (57\%), lung hypertension (47\%), dyspnoe (66\%), dysphagia (41\%), significant fatigue (96\%), erectile dysfunction (47\%), bone marrow failure (45\%) $[19,24]$. Hemoglobinuria is the most remarkable $\mathrm{PNH}$ symptom. It develops in nearly all patients during the disease, being, however, initially observed only in $26 \%$ of the cases [22, 24]. Thromboses represent the main reason of mortality ( 40 to $67 \%$ of lethal out- comes) followed by chronic kidney injury ( 8 to $18 \%$ of total), infections (17\%), and bleedings (8\%) [15, 23].

PNH symptoms exert significant negative effects upon quality of life due to anemia, transfusion dependence, abdominal and chest pain, sufficient fatique, dyspnoe which often need hospitalization and symptomatic drug medication.

PNH diagnostics may be quite difficult, due to variability of symptoms and rarity of the disorder. However, the time of diagnostics may be more rapid when using diagnostic algorithm and screening of high-risk patients [8]. Flow cytometry (FC) is considered the most sensitive and informative technique to establish PNH diagnosis. Percentage of blood cells with complete or partial GPI anchor deficiency shows the size of PNH clone, as measured by immune phenotyping performed with flow cytometry [1] 
National Clinical Guidelines on PNH diagnostics and treatment specify several patient groups with different clinical traits are discerned for appropriate PNH screening [16], i.e., Coombs-negative intravascular hemolysis; hemolytic anemia associated with hemoglobinuria, iron deficiency, cytopenia and thromboses; some bone marrow failure patterns (suggested or proven aplastic anemia; myelodysplastic syndrome (refractory cytopenia with 1-,2- or 3-lineage dyspla-sia, hypoplastic MDS variant), other cytopenias with unknown etiology after detailed examination; thromboses with atypical manifestations (uncommon localization, associated hemolytic anemia and cytopenias). As suggested in the Recommendations, optimal frequency of clinical examination and PNH screening should be performed initially in cases of aplastic anemia (AA) and MDS, and then twice a year in case of initial PNH clone detection. Presence of a PNH clone in MDS patients may be of high predictive value, with respect to its future treatment strategy.

Clinical Practice Guidelines in Oncology by National Comprehensive Cancer Network (NCCN-2010) recommend screening for PNH clone and HLA-DR15 if considering MDS. These markers seem to be best predictors of response to immunosuppressive therapy, especially, for younger patients ( $\leq 60$ years old) with normal cytogenetics and hypoplastic MDS variant [20].

So far, only symptomatic therapy was used for PNH therapy, i.e., iron supplement, folates, steroids, blood transfusions, anticoagulants in thrombotic episodes. Generally, the median survival for hemolytic PNH patients comprises 10 to 15 years from initial diagnosis. Thirty-five percent of these patients are lost within 5 years [8].

Hematopoietic stem cell transplantation (HSCT) is an approach which may be potentially curative in $\mathrm{PNH}$. However, HSCT is known to produce high complication rates, mortality, and is performed only for certain indications in cases of hematopoietic aplasia $[4,13]$.

Since 2007, Eculizumab, a drug for PNH target therapy, was registered for clinical use. Eculizumab is a humanized monoclonal antibody which is able to specifically bind the C5 component of complement system, thus blocking excessive complement activation and C5-mediated hemolysis, the main affecting factor in $\mathrm{PNH}$. International clinical trials and subsequent studies have shown that Eculizumab sufficiently decreased incidence of life-threatening complications (i.e., thromboses), and significantly improved survival of the PNH patients. $[7,14]$.

Current publications contain only few reports on successful treatment of combined PNH/MDS conditions. In available literature we did not find any data on clinical hematological remission achieved with Eculizumab therapy in patients $>70$ years old. Therefore, our own description of such clinical case treated by Eculizumab should have clinical practical value.

\section{Clinical case description}

Patient M., 73 years old, was admitted to a Department of Therapy in January 2016. He presented with significant fatigue, vertigo, dizziness, absence of appetite, icterus, dark urine, periodical pressing heart pain, low-grade fever over month, cough, dyspnoe upon modest physical loads. Anemic syndrome and thrombocytopenia are traced since 2006, specialized hematological examination was initiated since 2009. Bone marrow cytology showed megaloblastoid traits of erythroid cells evaluated as potential MDS markers. Glucocorticoid therapy did not provide clinical response. Special examination aiming to exclude paraneoplastic events, has shown a prostate carcinoma (pT2c, NO, G3, R0). The patient underwent extraperitoneal endoscopic radical prostatectomy with removal of regional pelvic lymph nodes, followed by urological screening, without any specific treatment. Since June 2015, his condition became worse, due to unmotivated fatigue, episodic hematuria. In January 2016, he noted some general physical symptoms as else-where described (see above), being admitted to Therapeutic Department. On admittance, his state was moderately severe. Skin and mucosae were icteric, multiple angiokeratomas and skin papillomas were evident. Peripheral lymph nodes were not enlarged, peripheral oedemas not detected. Chest auscultation did not show rales, however, weak breathing was evident. Heart sounds were muffled, at regular beats. Liver and spleen were not enlarged. Clinical blood analysis revealed decrease $\mathrm{Hb}(60 \mathrm{~g} / \mathrm{L}), \mathrm{RBCs}\left(1.75 \times 10^{12} / \mathrm{L}\right)$, platelets $\left(60 \times 10^{9} / \mathrm{L}\right)$, leukocytes $\left(5.4 \times 10^{9} / \mathrm{L}\right)$, neutrophils $(64 \%$ of total leukocyte counts). Urinalysis showed proteinuria $2.0 \mathrm{~g} / \mathrm{L}$, changed and fresh RBCs (100 to 120 per microscopic field), urobilinogen $(3+)$, bilirubin $(1+)$. Results of blood biochemistry were as follows: direct bilirubin $(21 \mu \mathrm{mol} / \mathrm{L})$, total bilirubin of 87 $\mu \mathrm{mol} / \mathrm{L}, \operatorname{ALaT}(31 \mathrm{U} / \mathrm{L})$, ASaT (108 U/L, LDH (2925 U/L, being much higher normal values of 125-245 U/L). On 13.01.16, ECG has shown a subendocardial anterior lateral myocardial infarction. EchoCG has shown apical hypokinesis, akinesia of anterior and anteriorseptal segments. Coronarographic study was refused, due to thrombocytopenia and hemorrhagic risk in the patient.

In view of distinct blood changes, we looked for PNH clonal markers. Flow cytometry provided the following pattern: type I (normal) RBCs, 59.05\%; type II (partial CD59 deficiency), 1.47\%; type III (complete lack of CD59 ), 39.48\%; monocytes with FLAER/CD14 deficiency - 92.02\%; granulocytes with FLAER/CD14 mangle - 94.73\%. Hence, a PNH clone was detectable among RBCs, monocytes and granulocytes in blood sample. Appropriate treatment consisted of $\mathrm{RBC}$ transfusions (6 standard doses), bisoprolol (5 $\mathrm{mg}$ ), isosorbide dinitrate (20 mg twice a day) followed by improvement of physical condition. Hb increased to $90 \mathrm{~g} / \mathrm{L}$, blood bilirubin and LDH levels remained high (resp., $28 \mu \mathrm{mol} / \mathrm{L}$, and $2124 \mathrm{U} / \mathrm{L}$ ). The patient was discharged from the clinic. In June 2016, he was urgently admitted to the M. Zhadkevich Municipal Clinical Hospital due to worsened clinical condition, recurrent skin icterus, dark urine, fever. His initial blood sampling was impossible due to intravascular hemolysis. Urine samples were brown-colored, with abundant yellow-brownish debris seen upon microscopy. Washed RBCs 
were transfused at this phase. At day +2 after admission, total blood analysis showed low Hb levels $(62 \mathrm{~g} / \mathrm{L})$, decreased platelet counts $\left(62 \times 10^{9} / \mathrm{L}\right)$. Routine blood chemistry showed LDH activity of $7132 \mathrm{U} / \mathrm{L}$ (reference, 125 to $245 \mathrm{U} / \mathrm{L}$ ), total bilirubin, $100 \mu \mathrm{Mol} / \mathrm{L}$ (direct bilirubin, $20 \mu \mathrm{mol} / \mathrm{L}$ ); ASAT, 290 U/L; C-reactive protein, 150 g/L. X-ray chest examination showed pneumonia in the left lower lobe. Further transfusion therapy included 3 doses of washed RBCs, and antibacterial treatment with Amoxicilline clavulanate, and Azithromycin. Relative stabilization of clinical state was observed. However, the course of disease was complicated by significant thrombocytopenia (to $18-20 \times 10^{9} / \mathrm{L}$ ), profuse nasal bleeding, instability of respiratory and cardiovascular systems, thus re-quiring therapeutic nitrates, bisoprolol, continued antibacterial and detoxication therapy.

In view of pronounced intravascular hemolysis and generally severe condition of the patient, we then started pathogenetic treatment by Eculizumab at a dose of $600 \mathrm{mg}$ at a 7-day interval. Simultaneous vaccination for meningococcal infection was performed at this time. As an outcome, the pulmonary inflammation was resolved, urinary parameters were normalized, with anemia improved to some degree $(\mathrm{Hb}$ level increased to $87 \mathrm{~g} / \mathrm{L}$ ).

Seven days after $2^{\text {nd }}$ eculizumab infusion, the patient was hospitalized to the Department of Hematology of Clinical Research Center at the Moscow Health Department, to specify further therapy. Upon admission, the patient was in satisfactory condition. Skin was of normal colour, eye sclerae were subicteric, hemorrhagic syndrome was not detectable. Hemodynamics remained stable, liver, spleen were of normal size. Blood analysis showed further increased $\mathrm{Hb}$ level $(95 \mathrm{~g} / \mathrm{L})$, erythrocytes $\left(3.0 \times 10^{12} / \mathrm{L}\right)$, platelets, $35 \times 10^{9} / \mathrm{L}$, leukocytes $\left(3.2 \times 10^{9} / \mathrm{L}\right)$; differential counts showed $48 \%$ neutrophils. Urinalysis showed low protein content $(0.1 \mathrm{~g} / \mathrm{L})$, erythrocytes (1-4 per vision field). Serum indexes were as follows: total bilirubin, $21 \mu \mathrm{mol} / \mathrm{L}$ (direct, $2.5 \mu \mathrm{mol} / \mathrm{L}$ ), LDH, 540 U/L (reference, 125-245 U/L).

Marrow cytology revealed $2.3 \%$ blast cells, with dysplastic traits of granulocyte lineage (Peulger-like, hyposegmentation of the nuclei), erythroid cells (megaloblasts, increased pyknosis rates), and megakaryocytic lineage (mononuclear or small megakaryocytes). Cytogenetic data exhibited complex aberrations: 45,X, -Y[16]/ 46,XY[4]nucish(DXZ1x1) [66] (DXZ1,DYZ3)x1[34]. Loss of Y chromosome was shown in $80 \%$ of the cells studied.

Hence, the following diagnosis has been established: Paroxismal nocturnal hemoglobinuria. Myelodysplastic syndrome. Refractory cytopenia with multilinear dysplasia. IPSS: intermediate 1 risk. Prostate carcinoma (pT2c, NO,M0. $\mathrm{G} 3, \mathrm{R} 0$ ). Extraperitoneal endoscopic radical prostatectomy of 2009. Due to observed clinical effect, we decided to continue Eculizumab treatment, according to a standard schedule. This mode of therapy proved to be tolerable, without adverse events during the infusions. Time-dependent dynamics of main blood indexes and changes in leukocyte profiles during such therapy are presented at Fig. 1 and Table 2.

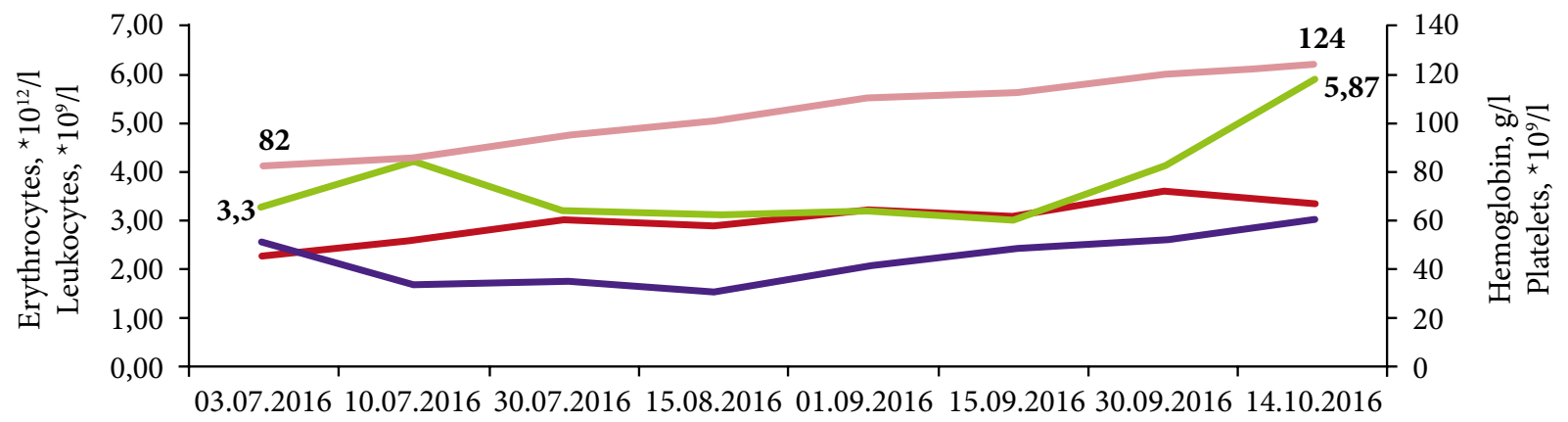

$\longrightarrow \mathrm{RBC} \longrightarrow \mathrm{WBC} \longrightarrow \mathrm{Hb} \longrightarrow \mathrm{Plt}$

Figure 1. Time course of hematological indexes during eculizumab therapy.

Table 2. Time dynamics of leukocyte profiles during Eculizumab therapy

\begin{tabular}{|llllllllll|}
\hline Parameter & 03.07 & 10.07 & 30.07 & 15.08 & 1.09 & 15.09 & 30.09 & 14.10 & Normal \\
\hline Band forms [\%] & 2 & - & - & 6 & 4 & - & 12 & - & $1-6$ \\
\hline Segmented forms [\%] & 51 & - & - & 42 & 52 & - & 46 & -- & $41-72$ \\
\hline Eosinophils [\%] & 1 & - & - & - & 2 & - & - & & $0,5-5$ \\
\hline Lymphocytes [\%] & 38 & - & 34,8 & 46 & 34 & 33,9 & 36 & - & $19-37$ \\
\hline Monocytes [\%] & 8 & - & 10,1 & 6 & 8 & 8,8 & 5 & $3-11$ \\
\hline ESR [mm/h] & 6 & - & 36 & 4 & 23 & 44 & 15 & 10 & $2-10$ \\
\hline
\end{tabular}


As seen from Fig. 1, the $\mathrm{Hb}$ levels did gradually increase to reference values, i.e., $120-125 \mathrm{~g} / \mathrm{L}$, leukocytes, to $4.1-5.87 \times 10^{9}$. Thrombocytopenia also became clinically insignificant $\left(53-60 \times 10^{9}\right)$.
LDH activity is shown to be increased in disorders accompanied by tissue damage and cell destruction. Therefore, this parameter is an important marker of tissue decay, chronical hemolysis. Fig. 2 shows changes in LDH activity during Eculizumab therapy.

Start of Eculizumab treatment

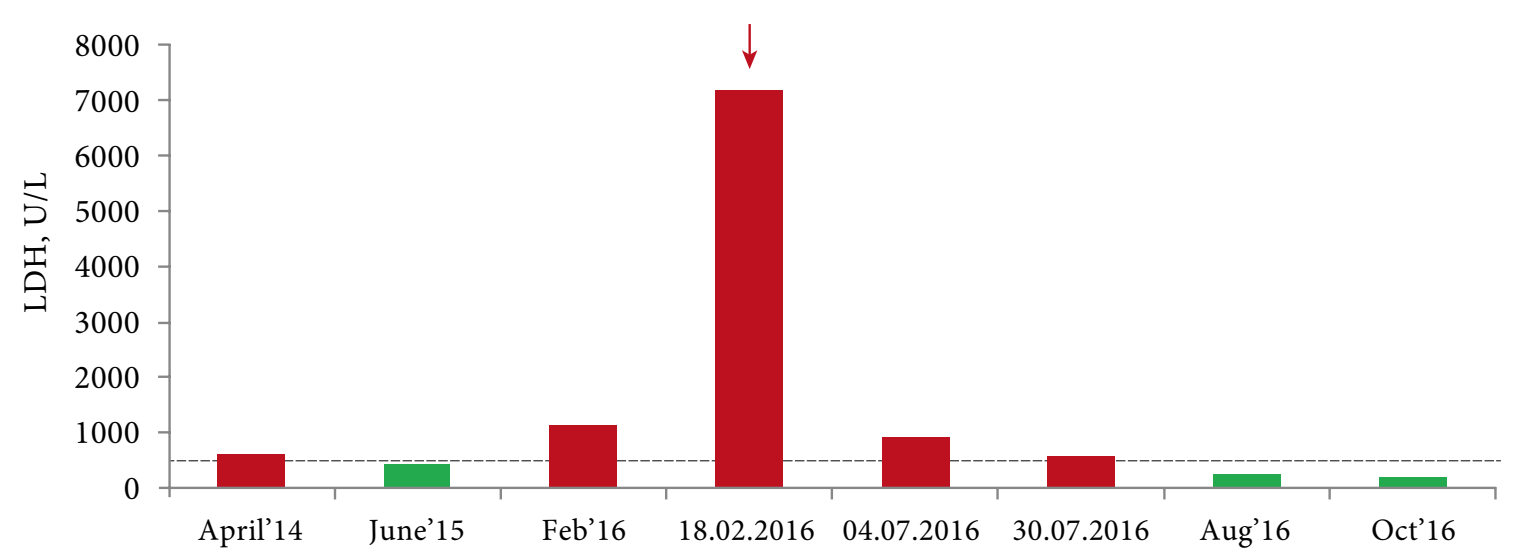

Figure 2. LDH changes with time after Eculizumab treatment.

As seen from Fig. 2, PNH progression was noted by increased LDH levels from April 2014 to February 2016. Positive dynamics of the disease was then seen as proven by decreased LDH levels and $\mathrm{Hb}$ normalization (Fig. 1), when continuing treatment. The patient reported improved physical condition, he has resumed usual physical loads. Eculizumab treatment is continued at a dose of $900 \mathrm{mg}$ once every 2 weeks.

\section{Discussion}

Historically, the PNH patients received symptomatic treatment, e.g., transfusion of washed RBCs, anticoagulant drugs, iron supplement and folic acid, glucocorticosteroids etc. HSCT was introduced is a method of choice for PNH therapy. Despite wide use of anticoagulants in $\mathrm{PNH}$ for thrombosis prophylaxis, appropriate risk in the patients remain high, thus enhancing bleeding risks as well [14]. Advent of Eculizumab, a monoclonal antibody which inhibits complement activity, has sufficiently improved results of PNH treatment due to effective control of complement-mediated hemolysis causing thromboses, and improving total survival of the patients $[5,17]$.

HCT remains the only curative method for PNH. According to large retrospective study which involved $211 \mathrm{PNH}$ patients treated with BMT, total 5-year survival in this cohort was $68 \%$, whereas graft failure was observed in $6 \%$ of the cases. Acute or chronic GvHD was evident in one-third of the patients $[4,5]$. Meanwhile, Loschi M. et al reported total 6-year survival of $92 \%$ among the patients treated by Eculizumab [17]. Hence, HSCT provides a chance for radical PNH treatment. However, lethality and potential complications of the procedure are poorly predictable, and HSCT, therefore, cannot be recommended as a first-line strategy in the patients with classic $\mathrm{PNH}[6]$.

In some cases, HSCT is considered an option of MDS treatment as first-line strategy. According to National Clinical
Guidelines for Diagnostics and Treatment of Adult MDS, HSCT is indicated for the patients from the Group 1-2 intermediate and high-risk IPSS scores. Cumulative mortality after allo-HSCT from HLA-identical siblings in 387 patients with MDS proved to be $37 \%$ within 3 years, whereas relapse rates were $23 \%$ during this time period, with overall 3 -year survival of $40 \%$, according to IBMTR data. The disease stage and number of blasts are more significant to the HSCT outcomes. However, upper age limits for HSCT do not exceed 65-70 years [26].

Our clinical case demonstrates clinical remission in an elderly $\mathrm{PNH}$ patient with myelodysplastic syndrome and high comorbidity burden. This case also shows importance of immune phenotyping for $\mathrm{PNH}$ clone detection in either patient with myelodysplastic syndrome. The patient had several indications for PNH clone testing, including cytopenia due to suggested MDS syndrome, intravascular hemolysis traits, and arterial thrombosis.

It is known that poorly documented MDS may be confused with unrecognized classical $\mathrm{PNH}$, since in many instances it may be interpreted as isolated cytopenia, with non-detected active intravascular hemolysis. In this view, our clinical observation contains sufficient criteria for MDS diagnostics, i.e., erythroid hyperplasia and dysplasia typical to $\mathrm{PNH}$, along with distinct cytological features of granulocytic and megakaryocytic dysplasia, like as clonal cytogenetic aberration (Y chromosome loss). Certainly, therapeutic choice in such cases cannot be based on the MDS treatment standards only. One should consider rates of intravascular hemolysis and, therefore, arrange target treatment with Eculizumab, according to current clinical indications. In this case, intensive intravascular hemolysis was followed by RBC transfusions, being then complicated by myocardial infarction, thus being indicative for appropriate target therapy, according to current recommendations. Marked positive response to Eculizumab treatment confirms a leading pathogenetic role of 
hemolysis rather than of bone marrow failure, for the profound anemia observed in this case. Further accumulation of blood immunophenotyping results, cytogenetic and cytological data will specify the $\mathrm{PNH}$ clone frequency and its pathogenetic role in MDS.

\section{Conflict of interest}

No conflict of interests is reported.

\section{References}

1. Borowitz MJ, Craig FE, Digiuseppe JA, Illingworth AJ, Rosse W, Sutherland DR, Wittwer CT, Richards SJ. Guidelines for the diagnosis and monitoring of paroxysmal nocturnal hemoglobinuria and related disorders by flow cytometry. Cytometry B ClinCytom. 2010;78(4):211-230.

2. Brodsky RA. Advances in the diagnosis and therapy of paroxysmal nocturnal hemolobinuria. Blood Rev. 2008;22(2):65-74.

3. de Latour RP, Mary JY, Salanoubat C, Terriou L, Etienne G, Mohty M, Roth S, de Guibert S, Maury S, Cahn JY, Socié G. Paroxysmal nocturnal hemoglobinuria: natural history of disease subcategories. Blood 2008; 112(8):3099-3106.

4. de Latour RP, Schrezenmeier H, Mary J-Y, Bacigalupo A, et al., Stem cell transplantation for paroxysmal nocturnal haemoglobinuria: an ongoing joint study of the AAWP EBMT Group and the French Society of Haematology. Bone Marrow Transplantation. 2009;43:S57-S58

5. de Latour RP, Schrezenmeier H, Bacigalupo A, Blaise D, de Souza CA, Vigouroux S, Willemze R, Terriou L, Tichelli A, Mohty M, de Guibert S, Marsh JC, Passweg J, Yves Mary J, Socié G. Allogeneic stem cell transplantation in paroxysmal nocturnal hemoglobinuria. Haematologica. 2012;97(11):1666-1673.

6. Regis Peffault de Latour. Transplantation for bone marrow failure: current issues. Hematology Am Soc Hematol Educ Program. 2016 Dec 2;2016(1):90-98.

7. Hall C, Richards S, Hillmen P. Primary prophylaxis with warfarin prevents thrombosis in paroxysmal nocturnal hemoglobinuria (PNH). Blood 2003; 102(10): 3587-3591.

8. Hillmen P, Lewis SM, Bessler M, Luzzatto L, Dacie JV. Natural history of paroxysmal nocturnal hemoglobinuria. N EngJ Med 1995; 333(19):1253-1258.

9. Hillmen P, Muus P, Dührsen U, Risitano AM, Schubert J, Luzzatto L, Schrezenmeier H, Szer J, Brodsky RA, Hill A, Socié G, Bessler M, Rollins SA, Bell L, Rother RP, Young NS. Effect of the complement inhibitor eculizumab on thromboembolism in patients with paroxysmal nocturnal hemoglobinuria. Blood 2007(12);110:4123-4128.

10. Hillmen P, Elebute M, Kelly R, Urbano-Ispizua A, Hill A, Rother RP, Khursigara G, Fu CL, Omine M, Browne P, Rosse W. Long-term effect of the complement inhibitor eculizumab on kidney function in patients with paroxysmal nocturnal hemoglobinuria. Am J Hematol 2010;85(8):553-559.
11. Iwanaga M, Furukawa K, Amenomori T, Mori H, Nakamura H, Fuchigami K, Kamihira S, Nakakuma H, Tomonaga M. K, Amenomori T. Paroxysmal nocturnal hemoglobinuria clones in patients with myelodysplastic syndromes. Br J Haematol. 1998;102(2):465-474.

12. Johnson RJ, Hillmen P. Paroxysmal nocturnal hemoglobinuria: nature's gene therapy? Mol Pathol. 2002; 55(3):145152.

13. Kanakura Y, Ohyashiki K, Shichishima T, Okamoto S, Ando K, Ninomiya H, Kawaguchi T, Nakao S, Nakakuma $\mathrm{H}$, Nishimura J, Kinoshita T, Bedrosian CL, Valentine ME, Khursigara G, Ozawa K, Omine M. Safety and efficacy of the terminal complement inhibitor eculizumab in Japanese patients with paroxysmal nocturnal hemoglobinuria: the AEGIS clinical trial. Int J Hematol. 2011; 93(1):36-46.

14. Kelly RJ, Hill A, Arnold LM, Brooksbank GL, Richards SJ, Cullen M, Mitchell LD, Cohen DR, Gregory WM, Hillmen P. Long-term treatment with eculizumab in paroxysmal nocturnal hemoglobinuria: sustained efficacy and improved survival. Blood. 2011;117(25):6786-6792.

15. Kim JS, Jang JH, Lee JW, et al. Renal impairment is a risk factor for early mortality in patients with paroxysmal nocturnal haemoglobinuria (PNH). Haematologica. 2011; 96:112.

16. Kulagin AD, Lisukov IA, Ptushkin VV, Shilova YR, Tsvetaeva NV, Mikhailova YA. National clinical guidelines for the diagnosis and treatment of paroxysmal nocturnal hemoglobinuria. Oncohematology. 2014;9(2):20-28. (In Russian)

17. Loschi M, Porcher R, Barraco F, Terriou L, Mohty M, de Guibert S, Mahe B, Lemal R, Dumas PY, Etienne G, et al. Impact of eculizumab treatment on paroxysmal nocturnal hemoglobinuria: a treatment versus no-treatment study. Am J Hematol. 2016;91(4):366-370.

18. Movalia, M, Illingworth A, Weitz I, and Lim SH. Incidence of PNH clones by diagnostic code utilizing high sensitivityflow cytometry [poster]. Proc. $53^{\text {rd }}$ Annual Meeting of the American Society of Hematology. (San Diego, CA); Dec 10-13. 2011.

19. Muus P, Szer J, Schrezenmeier H, et al., Evaluation of paroxysmal nocturnal hemoglobinuria disease burden: the patient's perspective. Blood 2010; 116:1525.

20. National Comprehensive Cancer Network (NCCN) Clinical Practice Guidelines in Oncology: Myelodysplastic syndromes. NationalComprehensiveCancerNetwork (NCCN), 2010.

21. Okamoto T, Okada M, Takatsuka H et al. Relationship between immunological abnormalities and paroxysmal nocturnal haemoglobinuriaassociated clones in myelodysplastic syndromes. Br J Haematol. 2001; 114(3):731-733.

22. Parker C, Omine M, Richards S, Nishimura J, Bessler M, Ware R, Hillmen P, Luzzatto L, Young N, Kinoshita T, Rosse W, Socié G. Diagnosis and management of paroxysmal nocturnal hemoglobinuria. Blood. 2005;106 (12):3699-3709. 
23. Risitano AM, Rotoli B. Paroxysmal nocturnal hemoglobinuria: pathophysiology, natural history and treatment options in the era of biological agents. Biologics. 2008; 2(2):205-222.

24. Rother RP, Bell L, Hillmen P, and extracellular plasma hemoglobin: a novel mechanism of human disease. JAMA. 2005;293(13):1653-1662.

25. Santarone S, Bacigalupo A, Risitano AM, Tagliaferri E, Di Bartolomeo E, Iori AP, Rambaldi A, Angelucci E, Spagnoli A, Papineschi F, Tamiazzo S, Di Nicola M, Di Bartolomeo P. Hematopoietic stem cell transplantation for paroxysmal nocturnal hemoglobinuria: Long-term results of a retrospective study on behalf of the Gruppo Italiano Trapianto Midollo Osseo (GITMO). Haematologica 2010; 95(6):983-988.

26. Savchenko VG, Parovichnikova EN, Kokhno AV et al. National Clinical Recommendations for Diagnostics and Treatment of Myelodysplastic Syndromes in Adults. Hematologia i Transfusiologia. 2015; No.1 (Supp 4): 1-32 (In Russian).
27. Sugimori C, Mochizuki K, Qi Z, Sugimori N, Ishiyama K, Kondo Y, Yamazaki H, Takami A, Okumura H, Nakao S. Origin and fate of blood cells deficient in glycosylphosphatidylinositol-anchored protein among patients with bone marrow failure. Br J Haematol. 2009; 147(1):102-112.

28. Wang H, Chuhjo T, Yasue S, Omine M, Nakao S. Clinical significance of a minor population of paroxysmal nocturnal hemoglobinuriatype cells in bone marrow failure syndrome. Blood. 2002;100(12):3897-3902.

29. Wang SA, Pozdnyakova O, Jorgensen JL, Medeiros LJ, Stachurski D, Anderson M, Raza A, Woda BA. Detection of paroxysmal nocturnal hemoglobinuria clones in patients with myelodysplastic syndromes and related bone marrow diseases, with emphasis on diagnostic pitfalls and caveats. Haematologica. 2009;94(1):29-37.

30. Yenerel MN, Diz-Kucukkaya R, Besisik S, Aktan M, Nalcaci M, Dincol G, Hacihanefioglu A, Turgut M. Paroxysmal nocturnal hemoglobinuria clone in patients with myelodysplastic syndrome. Am J Hematol. 2001;68(1):64-65.

\title{
Редкий случай пароксизмальной ночной гемоглобинурии у пациента старше 70 лет с миелодиспластическим синдромом
}

\author{
Галина А. Дудина
}

ГБУЗ Московский клинический научно-практический Центр департамента здравоохранения, Москва, Россия

\section{Резюме}

Пароксизмальная ночная гемоглобинурия (ПНГ) является генетически обусловленным, приобретенным, клональным гематологическим заболеванием, при котором клетки крови утрачивают способность фиксировать на поверхности белки-ингибиторы системы комплемента - CD55 и CD59. Вследствие этого у больных развивается комплемент-опосредованный хронический внутрисосудистый гемолиз, наиболее тяжелым осложнением которого являются тромбозы. В рекомендациях международных групп по изучению ПНГ определены группы риска для выявления патологического клона, в число которых входят пациенты с миелодиспластическим синдромом (МДС). Приведено описание выявления клини- чески значимого ПНГ-клона у пожилого пациента с миелопластическим синдромом и позитивные результаты применения патогенетического лечения экулизумабом.

\section{Ключевые слова}

Пароксизмальная ночная гемоглобинурия, миелодиспластический синдром, диагностика, экулизумаб. 